DOI: http://dx.doi.org/10.1590/S0104-64972015002306

\title{
Morphological remarks on the peppermint shrimp Lysmata ankeri (Decapoda, Hippolytidae): implications for species identification of the L. wurdemanni complex
}

\author{
Douglas Fernandes Rodrigues Alves, Samara de Paiva Barros-Alves*, Gustavo Luis Hirose and Valter \\ José Cobo
}

(DFRA, SPBA, GLH) Universidade Federal de Sergipe (UFS), Laboratório de Carcinologia. Av. Marechal Rondon, s/no, Rosa Elze. 49100-000 São Cristóvão, Sergipe, Brazil. E-mails: (DFRA) douglas_biologo@ yahoo.com.br; (SPBA) barros_samara@hotmail.com; (GLH) gustavo_lh@hotmail.com. *Corresponding author.

(VJC) Universidade de Taubaté (UNITAU), Laboratório de Biologia Marinha, (LabBMar), Instituto de Biociências. Av. Tiradentes, 500, Centro. 12030-180 Taubaté, São Paulo, Brazil. E-mail: (VJC) vjcobo@ unitau.br

\begin{abstract}
This contribution reviews the morphology and the main diagnostic characters of the peppermint shrimp Lysmata ankeri. Individuals were sampled by scuba divers from August 2008 to June 2013 on the subtidal rocky bottom at Couves Island, on the coast of Sáo Paulo State, Brazil. In the laboratory, the individuals were analyzed morphologically, with emphasis on the characters used in the diagnosis of the species; measured as carapace length (CL); and photographed. Seventeen individuals of $L$. ankeri were analyzed with an average size of $6.9 \pm 2.0 \mathrm{~mm}$ CL. From the morphological analysis the following variations of the diagnosis were observed: five teeth on the dorsal margin of the rostrum, in the diagnosis this was 6-8; five spines on the flexor margin of the dactyli of pereiopods 2-4, in the diagnosis this was 3-4. The records of this study extend the knowledge of the variation of some morphological characteristics for this species, resulting in an overlap among the species of the Lysmata wurdemanni complex.
\end{abstract}

Key words: Caridea, Hippolytidae, Lysmatidae, Morphology, Peppermint shrimp.

\section{INTRODUCTION}

The genus Lysmata Risso, 1816, belongs to the family Hippolytidae Spence Bate, 1888 (sensu Chace, 1997) and contains about 40 described species (Chace, 1997; Rhyne and Lin, 2006; Rhyne and Anker, 2007; Baeza and Anker, 2008; Anker et al., 2009; De Grave and Fransen, 2011), of which at least 12 species occur in the western Atlantic (Chace, 1972; Rhyne and Lin, 2006). Several studies in the last decade have provided new information, describing new species and reviewing the geographic distribution of this genus (e.g. Wicksten, 2002a; 2002b; Rhyne and Anker, 2007; Baeza and Anker, 2008; Anker et al., 2009; Laubenheimer and Rhyne, 2010).
The genus Lysmata can be distinguished from other genera by its moderately slender body, a long and thickened second pereiopod with a multi-articulated carpus, the rostrum armed with teeth on both dorsal and ventral margins, the welldeveloped arthrobranchs and exopods on the third maxilliped and the absence of a supraorbital spine (Abele and Kim, 1986; Holthuis, 1993; Chace, 1997).

These shrimps can display different and, in some cases, striking color patterns, which can be also used for species identification, such as Lysmata amboinensis (De Man, 1888) and Lysmata grabhami (Gordon, 1935) (Lin, 2004). However, the identification by means of the color pattern should be used with caution, since the coloration can be lost in animals preserved in formalin or 
alcohol solutions. Furthermore, differences can be subtle; for example, the species belonging to the Lysmata wurdemanni complex (Gibbes, 1850), which have a color pattern consisting of semitranslucent bodies with longitudinal and lateral red bands (Rhyne and Lin, 2006).

Based on a revision of the species of the $L$. wurdemanni complex, Rhyne and Lin (2006) described four species: Lysmata ankeri, Lysmata bahia, Lysmata boggessi and Lysmata pederseni, and redescribed two species, Lysmata rathbunae Chace, 1970 and L. wurdemanni, all restricted to the western Atlantic. In addition, Lysmata udoi was described by Baeza et al. (2009a), but its morphology and color pattern suggest that this species also belongs to the L. wurdemanni complex.

Rhyne and Lin (2006) proposed a key for identification of the species pertaining to the L. wurdemanni complex, based on distinct morphological characteristics. Although these morphological characteristics present a wide variation for most of the species of the $L$. wurdemanni complex, they still have a great taxonomic importance (Rhyne and Lin, 2006). Thus the constant revision and expansion of such morphological variations is essential to ensure the correct identification of the species. In this study we reviewed the morphology of the main diagnostic characters of $L$. ankeri obtained on the northern coast of São Paulo State, southeastern Brazil.

\section{Material ANd Methods}

Specimens of Lysmata ankeri (Fig. 1) were sampled during collections of other decapod crustaceans from August 2008 to June 2013 on the subtidal rocky bottom at Couves Island $\left(23^{\circ} 25^{\prime} 15^{\prime \prime} \mathrm{S}\right.$ 4451'39”W), Couves Archipelago, Ubatuba, Brazil. Samples were taken during daytime sessions of scuba diving, conducted by two divers from five to $15 \mathrm{~m}$ depth.

In the laboratory, the individuals were identified according to Rhyne and Lin (2006). Each specimen was measured for the rostrum (RL) and carapace length (CL), using a stereomicroscope equipped with an imaging and measurement tool (Zeiss Stemi DV4, accuracy $0.01 \mathrm{~mm}$ ). Each specimen of $L$. ankeri was analyzed for the diagnostic morphological characters presented by Rhyne and Lin (2006).
The specimens were deposited in the Scientific Collection of Carcinology, Laboratory of Marine Biology, University of Taubaté and in the Carcinological Collection of the Museum of Zoology of the University of São Paulo (MZUSP 32641, two specimens).

\section{RESUlTS}

A total of 17 individuals of Lysmata ankeri were sampled on the rocky bottom and in crevices and natural burrows formed by the rocks. The individuals were apparently solitary, or in small or large groups (fewer than 10 individuals or more than 30 individuals, respectively). Other shrimps of the Lysmata wurdemanni complex live in groups, such as L. wurdemanni, Lysmata boggessi, Lysmata bahia and Lysmata udoi. However, some species, such as L. udoi and Lysmata pederseni, show symbiotic behavior (e.g. living in association with fishes and sponges) (Rhyne and Lin, 2006; Baeza et al., 2009a; 2009b; Baeza, 2010).

The CL ranges from $3.6 \leq 10.3 \mathrm{~mm}$ (mean $6.9 \pm 2.0 \mathrm{~mm} \mathrm{CL}$ ) and RL from 2.8 to $8.2 \mathrm{~mm}$ (mean $5.4 \pm 1.6 \mathrm{~mm} \mathrm{RL})(\mathrm{n}=13)$. Rostrum 0.650.9 times as long as carapace, rarely reaching the end of third segment of antennular peduncle; dorsal margin of rostrum with 5-7 teeth (predominantly six) (Fig. 2A-C); ventral margin of rostrum with 3-6 teeth (predominantly four) (Fig. 2A-C). Carapace robust, three-fourths as high as long, forming an obtuse angle at most ventral margin; ventro-posterior margin of carapace not well rounded, flattened posteriorly. Eyes large, covering the dorsal surface of rostrum. Antennule with stylocerite reaching just beyond distal margin of eye. Antennal scale with a disto-lateral tooth, 3.4-4.5 times as long as wide. Carpus of second pereiopod with 3235 segments. Third-fifth pereiopods with dactyli biunguiculate; flexor margin with 2-4 spines (Fig. 2D-F). Fifth pereiopod with merus armed with 0-6 spines. Color in life - Body semitranslucent with red longitudinal, transverse, and oblique bands and stripes; carapace with broad and narrow oblique and transverse bands, some forming shallow U or V; abdominal pleura with narrow longitudinal stripes; telson and uropods with relatively narrow longitudinal stripes (see Fig. 1 A, B). 


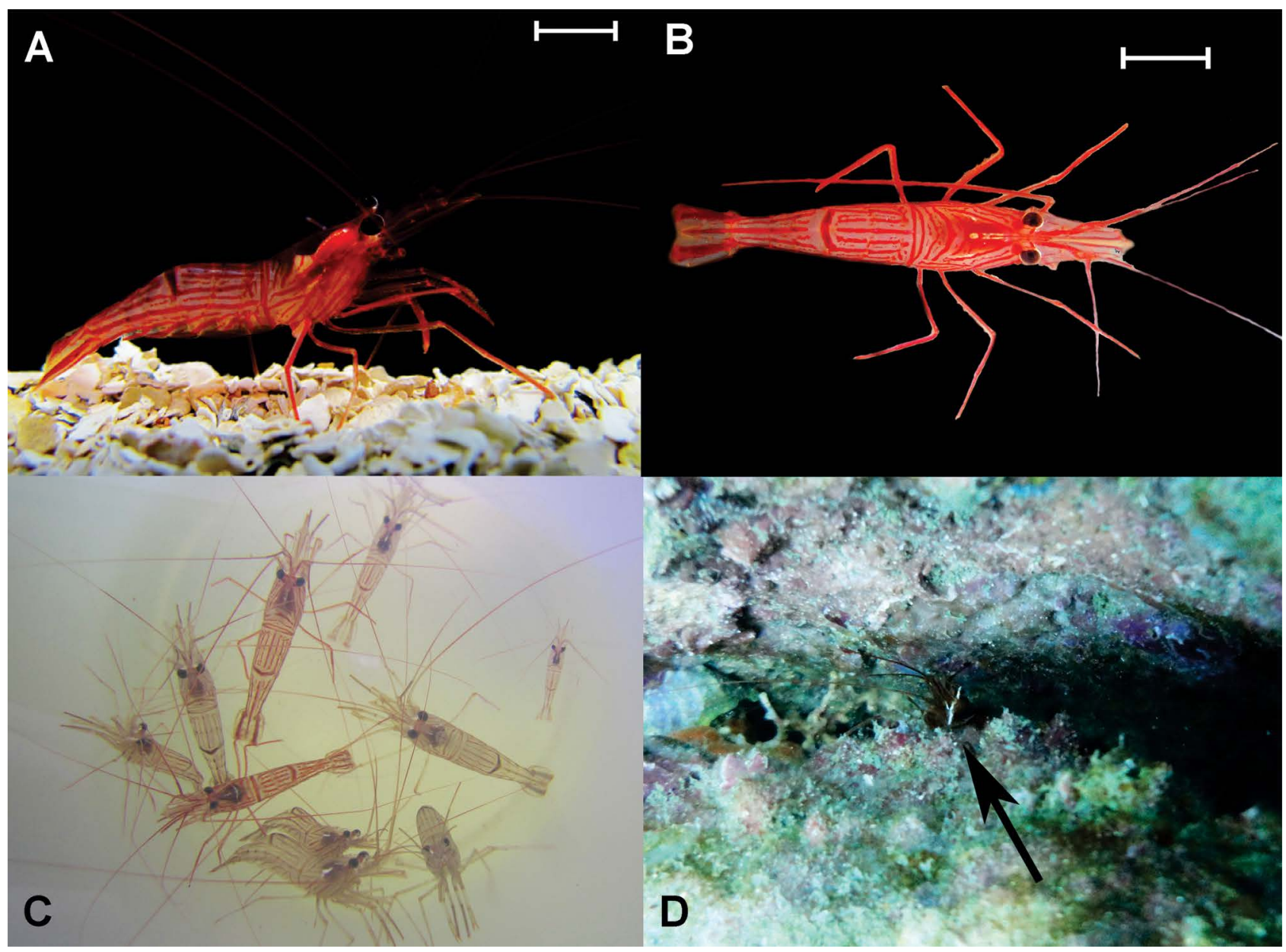

Figure 1. Lysmata ankeri. (A) Lateral view; (B) dorsal view; (C) some specimens in the laboratory after sampling; (D) an individual (indicated by the arrow) in rock crevice at the sampling site, on the subtidal rocky bottom at Couves Island, Ubatuba, Brazil (Photographs: DFR Alves). Scale bars $=5 \mathrm{~mm}$.

\section{Discussion}

The identification of shrimp used in this study was confirmed from different characters identified by Rhyne and Lin (2006). Among the characters that support this identification we can mention: 1) rostrum rarely reaching the end of third segment of antennular peduncle; 2 ) number of teeth in the ventral margin of rostrum; 3) number of spines in the merus of the fifth pereiopod; 4) number of segments in the carpus of the second pereiopod; 5) color pattern; 6) ecological remarks (see Tab. 1).

However, for two morphological characteristics, differences were recorded in relation to the diagnosis of Lysmata ankeri: 1) five teeth on the dorsal margin of the rostrum (6-8 teeth in the diagnosis) and 2) two spines on the flexor margin of the dactyli of pereiopods 3-5 (3-4 spines in the diagnosis). It is noteworthy that these specimens were in perfect condition, with no signs that the rostrum could have been broken or was regenerating.
Based on these data, we suggest the expansion of the lower limit of the variation in the dentition of the dorsal surface of the rostrum and the spines on the flexor margin of the dactyli, proposed in the diagnosis of this species by Rhyne and Lin (2006). Thus, $L$. ankeri may have five teeth on the dorsal margin of the rostrum, similarly to Lysmata boggessi, Lysmata rathbunae, Lysmata udoi and Lysmata wurdemanni; and it may also have two spines on the flexor margin of the dactyli of pereiopods 3-5, similarly to Lysmata bahia, Lysmata pederseni, L. udoi and L. wurdemanni (Rhyne and Lin, 2006; Baeza et al., 2009a) (see Tab. 1).

Many species descriptions are based on a small number of specimens, from one or a few localities. Indeed, the total variation in morphological diagnostic characters may be unknown (e.g. Burukovsky, 2000; Rhyne and Anker, 2007; Okuno and Fiedler, 2010). 

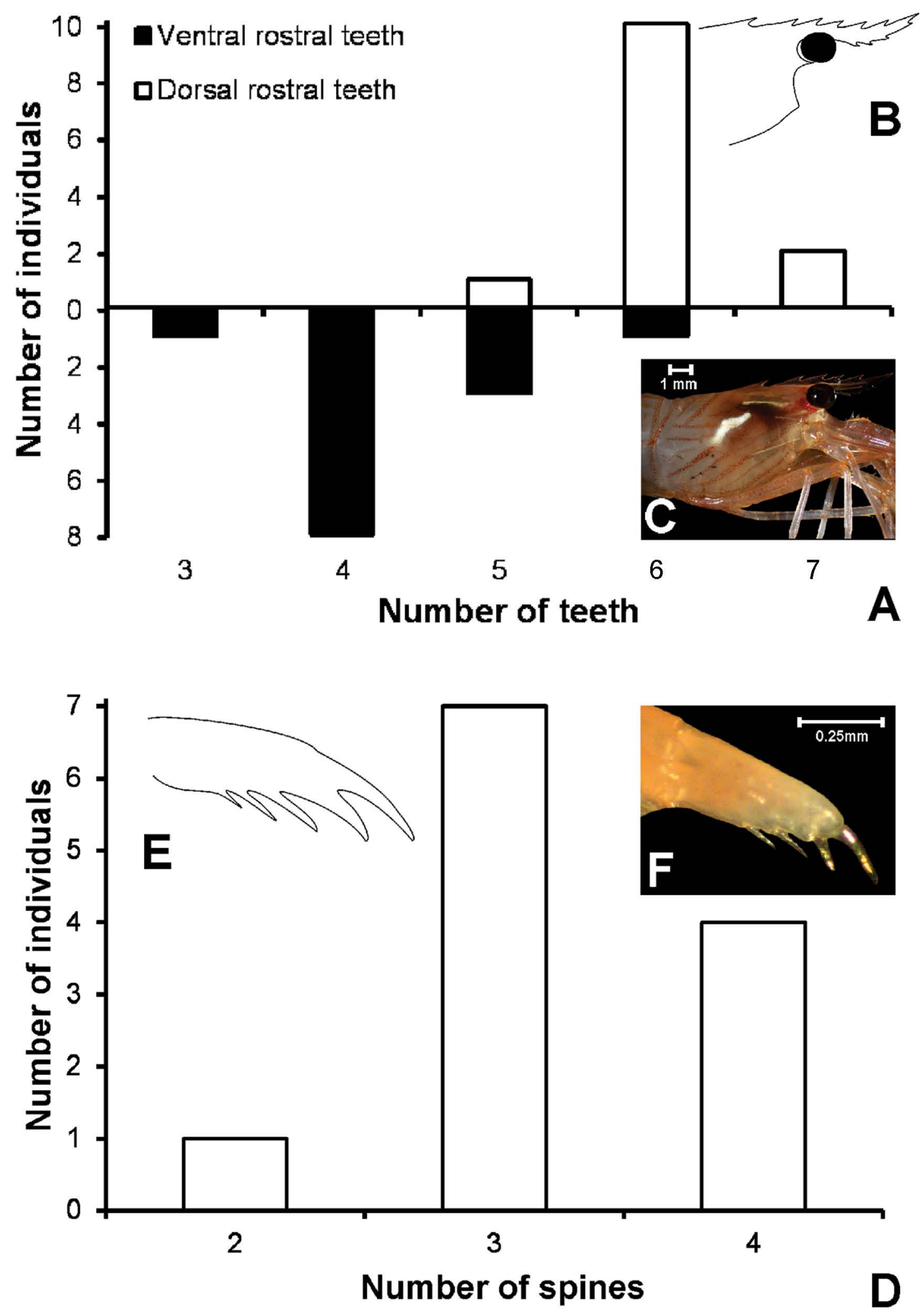

Figure 2. Lysmata ankeri. (A) Variation in the number of rostral teeth on the dorsal and ventral margins; (B) predominant rostral dentition; (C) dorsal rostral dentition with 5 teeth (Photograph: DFR Alves); (D) variation in the number of spines on the flexor margin of the dactylus of the pereiopod; (E) dactylus with the predominant number of spines; (F) dactylus with 2 spines (Photograph: DFR Alves). 
Table 1. Comparison of morphological characteristics of Lysmata ankeri captured on the subtidal rocky bottom at Couves Island, northern coast of São Paulo State with other species on the on the Lysmata wurdemanni complex.

\begin{tabular}{|c|c|c|c|c|c|c|c|c|}
\hline Characteristics & $\begin{array}{l}\text { Lysmata } \\
\text { ankeri }^{1}\end{array}$ & $\begin{array}{l}\text { Lysmata } \\
\text { ankeri }^{2}\end{array}$ & Lysmata bahia ${ }^{2}$ & $\begin{array}{l}\text { Lysmata } \\
\text { boggessi }\end{array}$ & $\begin{array}{c}\text { Lysmata } \\
\text { pederseni }^{2}\end{array}$ & $\begin{array}{c}\text { Lysmata } \\
\text { rathbunae }\end{array}$ & Lysmata udoi ${ }^{4}$ & $\begin{array}{c}\text { Lysmata } \\
\text { wurdemanni }\end{array}$ \\
\hline $\begin{array}{l}\text { Rostrum } \\
\text { length }\end{array}$ & $\begin{array}{l}0.65-0.9 \\
\text { times as long } \\
\text { as carapace, } \\
\text { reaching } \\
\text { usually to } \\
\text { middle, rarely } \\
\text { past the end of } \\
\text { third segment } \\
\text { of antennular } \\
\text { peduncle }\end{array}$ & $\begin{array}{l}\text { 0.6-0.8 times } \\
\text { as long as } \\
\text { carapace, } \\
\text { reaching } \\
\text { usually to } \\
\text { middle, rarely } \\
\text { past the end of } \\
\text { third segment } \\
\text { of antennular } \\
\text { peduncle }\end{array}$ & $\begin{array}{l}0.5 \text { times } \\
\text { as long as } \\
\text { carapace, } \\
\text { reaching level } \\
\text { of middle of } \\
\text { intermediate } \\
\text { segment of } \\
\text { antennular } \\
\text { peduncle }\end{array}$ & $\begin{array}{c}\text { 0.6-1.0 (rarely } \\
>0.8 \text { ) times } \\
\text { as long as } \\
\text { carapace, } \\
\text { reaching } \\
\text { at least to } \\
\text { middle, or } \\
\text { to distal } \\
\text { margin of } \\
\text { intermediate } \\
\text { segment of } \\
\text { antennular } \\
\text { peduncle }\end{array}$ & $\begin{array}{l}0.7-1.1 \text { times } \\
\text { as long as } \\
\text { carapace, } \\
\text { reaching at } \\
\text { least level of } \\
\text { end of distal } \\
\text { segment of } \\
\text { antennular } \\
\text { peduncle }\end{array}$ & $\begin{array}{l}\text { Long, } \\
\text { reaching } \\
\text { beyond distal } \\
\text { margin of } \\
\text { third segment } \\
\text { of antennular } \\
\text { peduncle }\end{array}$ & $\begin{array}{c}0.9 \text { times } \\
\text { as long as } \\
\text { carapace, } \\
\text { slightly } \\
\text { surpassing end } \\
\text { of antennular } \\
\text { peduncle }\end{array}$ & $\begin{array}{l}\text { 0.4-0.7 times } \\
\text { as long as } \\
\text { carapace, } \\
\text { reaching } \\
\text { at least to } \\
\text { middle of } \\
\text { intermediate } \\
\text { segment of } \\
\text { antennular } \\
\text { peduncle }\end{array}$ \\
\hline $\begin{array}{l}\text { Number of } \\
\text { dorsal rostral } \\
\text { teeth }\end{array}$ & $5-7$ & $6-8$ & $6-7$ & $\begin{array}{c}4-5 \text { (rarely } 3 \\
\text { or } 6)\end{array}$ & $\begin{array}{c}7-8(\text { rarely } 9 \\
10 \text { or } 11)\end{array}$ & $5-6$ & 6 & $4-6$ \\
\hline $\begin{array}{l}\text { Number of } \\
\text { ventral rostral } \\
\text { teeth }\end{array}$ & $3-6$ & $3-7$ & $3-4$ & $\begin{array}{c}3-5 \text { (rarely } 2 \\
6 \text { or } 7)\end{array}$ & $\begin{array}{c}5-7 \text { (rarely } 8 \\
\text { or } 9)\end{array}$ & $3-5$ & 5 & $\begin{array}{c}4 \text { (rarely } 2,3 \\
5 \text {, or } 6)\end{array}$ \\
\hline $\begin{array}{l}\text { Number of } \\
\text { spines on } \\
\text { merus of } \\
\text { pereiopod } 5\end{array}$ & $3-5$ & $0-6$ & $1-6$ & $3-6$ & $3-6$ & $3-5$ & 3 & $1-4$ \\
\hline $\begin{array}{l}\text { Number } \\
\text { of carpal } \\
\text { segments on } \\
\text { pereiopod } 2\end{array}$ & $33-35$ & $33-41$ & $29-31$ & $25-32$ & $33-41$ & $30-35$ & 20 & $27-30$ \\
\hline $\begin{array}{l}\text { Number of } \\
\text { spines on the } \\
\text { flexor margin } \\
\text { of the dactylus } \\
\text { of pereiopods } \\
3-5\end{array}$ & $2-4$ & $3($ rarely 4$)$ & 2 (rarely 3$)$ & $\begin{array}{c}4-5 \text { (rarely } 3 \\
\text { or } 6)\end{array}$ & 3 (rarely 2) & 3-4 (usually 3) & 7 & $\begin{array}{c}3 \text { (rarely } 2 \\
\text { or } 4)\end{array}$ \\
\hline
\end{tabular}

For example, Laubenheimer and Rhyne (2010) described a new species of peppermint shrimp, Lysmata rauli, and in a subsequent study, Soledade et al. (2013) showed, based on morphological characters, color pattern and genetics, that $L$. rauli is not a new species endemic to Brazil but rather is a junior synonym of Lysmata vittata (Stimpson, 1860) from the Indo-Pacific.

This study contributes to the expansion of the variation limits of the number of teeth on the dorsal margin of the rostrum and the number of spines on the flexor margin of the dactyli in $L$. ankeri. Recognition of the morphological variation is useful for the correct identification of individuals from $L$. wurdemanni complex (Rhyne and Lin, 2006; Anker et al., 2009). Thus, we encourage continuous reviews of diagnostic morphological characters for the largest possible number of individuals obtained throughout the geographic distribution of a species.

\section{ACKNOWLEDgMENTS}

The authors are indebted to Dr. Janet Reid for her constructive comments on early drafts of the manuscript and help with the English language. All sampling in this study was conducted in compliance with applicable state and federal laws (IBAMA/ICMBio/SISBIO\#16101-1 and 16101-2).

\section{REFERENCES}

Abele, L.G. and Kim, W. 1986. An illustrated guide to the marine decapod crustaceans of Florida. State of Florida Department of Environmental Regulation Technical Series, 8(1, part 1): 1-225.

Anker, A.; Baeza, J.A. and De Grave, S. 2009. A new species of Lysmata (Crustacea: Decapoda: Hippolytidae) from the Pacific coast of Panama, with observations of its reproductive biology. Zoological Studies, 48: 682-692.

Baeza, J.A. 2010. The symbiotic lifestyle and its evolutionary consequences: social monogamy and sex allocation in the hermaphroditic shrimp Lysmata pederseni. Naturwissenschaften, 97: 729-741. 
Baeza, J.A. and Anker, A. 2008. Lysmata hochi n.sp., a new hermaphroditic shrimp from the southwestern Caribbean sea (Caridea: Hippolytidae). Journal of Crustacean Biology, 28: 148-155.

Baeza, J.A.; Bolaños, J.A.; Hernandez, J.E. and López, R. 2009a. A new species of Lysmata (Crustacea, Decapoda, Hippolytidae) from Venezuela, southeastern Caribbean Sea. Zootaxa, 2240: 60-68.

Baeza, J.A.; Schubart, C.D.; Zillner, P.; Fuentes, S. and Bauer, R.T. 2009b. Molecular phylogeny of shrimps from the genus Lysmata (Caridea: Hippolytidae): the evolutionary origins of protandric simultaneous hermaphroditism and social monogamy. Biological Journal of the Linnean Society, 96: 415-424.

Burukovsky, R.N. 2000. Lysmata splendida sp. nov., a new species of shrimp from the Maldives (Crustacea: Decapoda: Hippolytidae). Senckenbergiana Maritima, 30(3/6): 223-227.

Chace, F., Jr. 1970. A new shrimp of the genus Lysmata (Decapoda, Hippolytidae) from the Western Atlantic. Crustaceana, 19: 59-66.

Chace, F.A. Jr. 1972. The shrimps of the Smithsonian-Bredin Caribbean Expeditions with a summary of the West Indian shallow-water species (Crustacea: Decapoda Natantia). Smithsonian Contributions to Zoology, 98: 1-179.

Chace, F.A. Jr. 1997. The Caridean Shrimps (Crustacea: Decapoda) of the Albatross Philippine Expedition, 1907-1910, Part 7: Families Atyidae, Eugonatonotidae, Rhynchocinetidae, Bathypalaemonellidae, Processidae and Hippolytidae. Smithsonian Contribution to Zoology, 587: 1-106.

DeGrave, S. and Fransen, C.H.J.M. 2011. Carideorum catalogus: the recent species of the dendrobranchiate, stenopodidean, procarididean and caridean shrimps (Crustacea: Decapoda). Zoologische Mededelingen, 85(9): 195-588.

Holthuis, L.B. 1993. The recent genera of the caridean and stenopodidean shrimps (Crustacea, Decapoda) with an appendix on the order Amphionidacea. Leiden, Nationaal Natuurhistorisch Museum, 328p.
Laubenheimer, H. and Rhyne, A.L. 2010. Lysmata rauli, a new species of peppermint shrimp, (Decapoda: Hippolytidae) from the southwestern Atlantic. Zootaxa, 2372: 298-304.

Lin, J. 2004. Aquaculture of ornamental marine shrimp provides alternative to wild collection. Global Aquaculture Advocate, 55-56.

Okuno, J. and Fielder, G. 2010. Lysmata lipkei, a new species of peppermint shrimp (Decapoda, Hippolytidae) from warm temperate and subtropical Waters of Japan. In: C.H.J.M. Fransen, S. De Grave and P.K.L. Ng (eds), Studies on Malacostraca: Lipke Bijdeley Holthuis Memorial Volume, Crustaceana Monographs, 14: 597610.

Rhyne, A.L. and Anker, A. 2007. Lysmata rafa, a new species of peppermint shrimp (Crustacea, Caridea, Hippolytidae) from the subtropical western Atlantic. Helgoland Marine Research, 61: 291-296.

Rhyne, A.L. and Lin, J. 2006. A western Atlantic peppermint shrimp complex: redescription of Lysmata wurdemanni (Gibbes), description of four new species and remarks on $L$. rathbunae Chace (Crustacea: Decapoda: Hippolytidae). Bulletin of Marine Science, 79: 165-204.

Soledade, G.O.; Baeza, J.A.; Boehs, G.; Simóes, S.M.; Santos, P.S.; Costa, R.C. and Almeida, A.O. 2013. A precautionary tale when describing species in a world of invaders: morphology, coloration and genetics demonstrate that Lysmata rauli is not a new species endemic to Brazil but a junior synonym of the IndoPacific L. vittata. Journal of Crustacean Biology, 33(1): 66-77.

Wicksten, M.K. 2002a. A new species of Lysmata (Caridea, Hippolytidae) from the eastern Pacific. Crustaceana, 73: 207-213.

Wicksten, M.K. 2002b. The species of Lysmata (Caridea: Hippolytidae) from the eastern Pacific Ocean. Amphipacifica, 2: 3-22. 